\title{
TECHNIQUES FOR THE STUDY OF SPIDER GENITALIA
}

\author{
By Herbert W. Levi * \\ Museum of Comparative Zoology
}

In response to many inquiries, I want to describe the techniques used for studying genitalia in the spider family Theridiidae. These procedures are not original, but have been adapted from methods used by several colleagues and students. One technique used in the family Araneidae is new and, I hope, helpful to students of that family.

I would like to urge strongly against making permanent microscopic slides of genitalia. Most slides are not permanent; even balsam may crystallize after fifty years. In dehydration, sclerotized parts may warp and, as the slide dries, the cover glass may crush anatomical structures. The slides often become separated from the parts of the specimen kept in alcohol and are lost. However, mounting the genitalia of common species on slides often saves time in their study. The medium found most useful is Hoyer's fluid (Baker and Wharton).

Luckily, most male spiders have two palpi. One, usually the left, is removed so that it can be turned to the desired angle. Palpi should always be examined completely submerged in 75 to $90 \%$ alcohol, never dry. Drying shrinks and distorts softer parts; partial submersion produces undesirable reflections. To prevent the parts from floating away in convection currents caused by the heat of the microscope light, the light is equipped with heat absorbing glass and the pedipalpus anchored in a piece of fibrous paper tissue at the bottom of the dish. Vaseline, sometimes recommended to keep the palpus in position, may cling to it, smear over it, and is difficult to remove. Examination is by binocular dissecting microscope, at magnifications of 150 to 240 times.

Small, translucent, weakly sclerotized palpi are common among theridiid spiders. A transfer to glycerine, after blotting off alcohol, may help to make visible the borders of transparent structures. A temporary slide mount in glycerine may be made for examination under a compound or phase microscope. The palpus should always be returned to alcohol in a microvial $\left(4 \times_{10} \mathrm{~mm}\right)$ stoppered with cotton, to be kept with the spider in a larger vial (Fig. I). A permanent mounting generally ruins the palpus for study, as sclerites become too transparent, may become distorted, and can not be turned

* Manuscript received by the editor November 4, 1964 


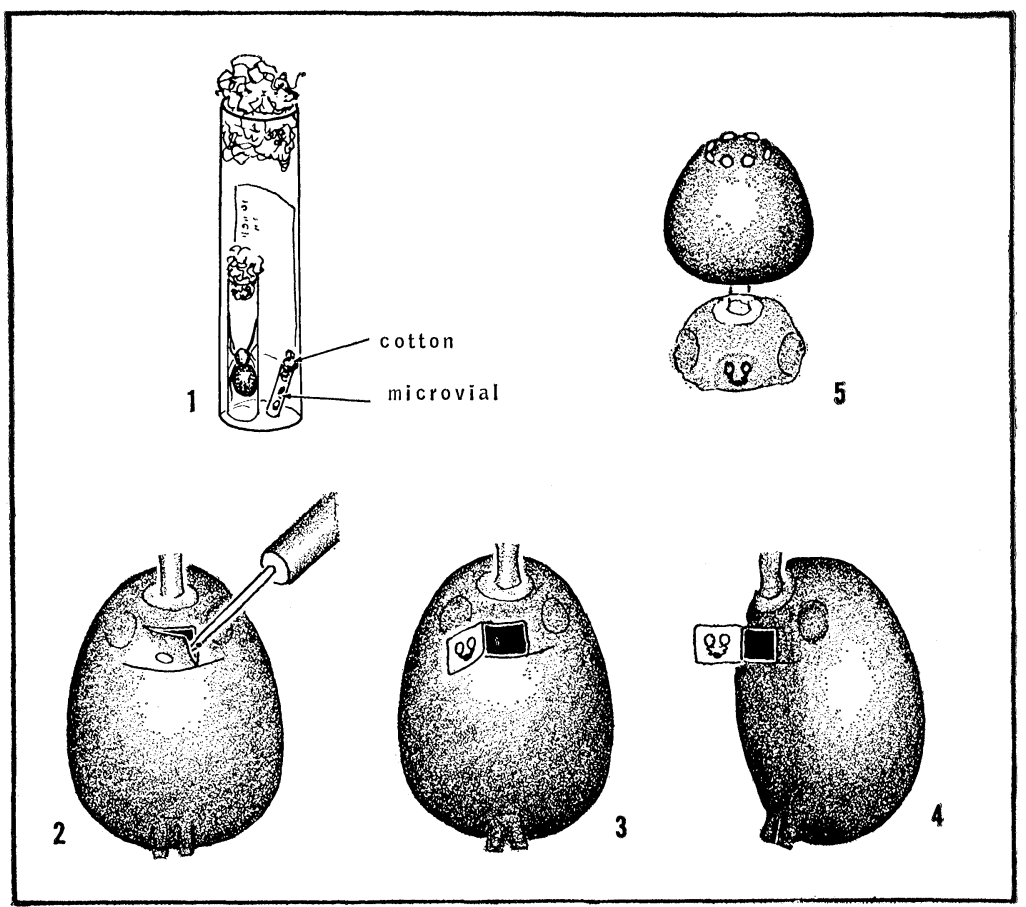

Figures 1-5. Techniques for the Study of Spider Genitalia. Fig. 1. Vial containing two smaller vials, all stoppered with cotton. Fig. 2. Abdomen, showing place of incision. Fig. 3. Abdomen with genital area bent over. Fig. 4. Abdomen positioned for drawing internal genitalia. Fig. 5. Part of cephalothorax with pedicel and abdomen integument including genitalia.

and placed conveniently. I have examined a few such slides of genitalia of holotypes only twenty years old; they were almost useless.

Expanding the palpus to examine the position of sclerites is of value in phylogenetic studies, but is rarely useful for descriptions intended to facilitate species recognition. After the alcohol is blotted off, the palpus is brought to boiling in $10 \% \mathrm{NaOH}$ solution. Then the palpus is transferred directly to distilled water where the hematodocha rapidly expands. The palpus can then be transferred to alcohol for storage. Unfortunately, boiling in $\mathrm{NaOH}$ warps, distorts and damages sclerites. Full strength lactic acid can be substituted for sodium hydroxide. Sclerotized palpi must be boiled longer than soft ones. 
The epigynum of holotypes or rare species should not be removed from the body of the specimen. In many small spiders, especially if the epigynum is weakly sclerotized, the whole spider can be dropped into clove oil, after first blotting to remove excess alcohol. This procedure is satisfactory for routine examination of Clubiona, Dipoena and other small spiders having little pigment. After a few minutes' clearing, the ducts can be seen; longer clearing makes them too transparent. In these two genera, specific determination is based on characteristics of the duct that loops between the seminal receptacle and the external plate. In other genera the ducts are behind the seminal receptacles. For description of new species, a more careful examination is necessary. After removal from clove oil, the spiders are again blotted and returned to alcohol for storage.***

The procedure used for more careful examination is to make two cuts around the genital area (Fig. 2). The tools used are mounted, sharpened insect pins (minuten nadeln). The epigynal plate with seminal receptacles is folded back (Fig. 3 ) before or during submersion in clove oil. The specimen is then anchored on fibrous paper tissue for exanination (Fig. 4). After examination the genitalia are bent back, like closing a door. In poorly preserved specimens the structure sometimes breaks off. In that case it should be stored in a microvial. On very small spiders it is advantageous at times to separate cephalothorax and abdomen, but the epigynum and neighboring integument should remain attached to the pedicel (Fig. 5). Sometimes a temporary slide can be made of the whole cephalothorax with genitalia.

If there are numerous specimens and difficulties in their study, it is best to make a temporary microscope slide of the epigynum with its accompanying structures. The epigynum is first cleared in clove oil and then, with a medicine dropper, it is transferred in a drop of clove oil to a microscope slide and covered with a coverglass. This preparation can be examined under a compound or phase microscope and the parts later returned to alcohol to be stored in a microvial. But there may be difficulties in this procedure. In Helvibis (Levi, I964) it was possible to follow the course of the tortuous (but diagnostic) epigynum ducts in only two species: one because the ducts were short and simple, the other because I could destroy one of the numerous specimens available and tease the ducts apart with needles.

\footnotetext{
**Prof. M. E. Galiano informed me that examination under oil may damage iridescence or structural colors.
} 
Boiling the female genitalia in $10 \% \mathrm{NaOH}$ may be necessary to clear heavily sclerotized parts, but this method invariably distorts and warps structures, swelling softer parts. It should only be used as an additional method if there are many specimens.

Among the numerous difficulties of taxonomic research in the family Araneidae (= Argiopidae) is the problem of matching males and females. They are often collected separately and may be different in appearance. Abalos recently (1963) observed, in his study of reproductive behavior of spiders, that during the mating of many species the tip of the male palpal embolus, presumably carrying sperm, breaks off and remains in the female genital ducts. Though this had been noticed before in black widows, it appears to be widespread in theridiid spiders and orb weavers. The reason it has been overlooked is that the majority of males collected are virgin, in search of a female; the tip of the embolus is therefore still attached in most males preserved in collections. Because they die soon after mating, mated males are rarely collected. On the other hand, probably the majority of females collected have mated. In the genus Argyope, now being studied, and presumably in other argiopids, the tip of the male embolus can readily be "fished out" of the epigynum by jiggling the projecting parts with a needle. Among related species of the genus Argyope, these tips differ strikingly in structure, athough the female genitalia are quite similar. An illustration of a broken off tip was supplied by Petrunkevitch (1930) with the hope of finding a male to match it. These tips not only permit matching males with females, but facilitate identification of females that have similar epigyna. Of course, the assumption is made that the male chose a mate of his own species. But the same method, applied to species in which the female is as easily determined as the male, may provide some data on the frequency of mating between species in nature.

I would like to thank Dr. A. M. Chickering, Mr. Jon Reiskind and my wife for editing, and Miss Vida Kenk and Mr. F. Vuilleumier for translating the summary. The investigations were supported by Public Health Service Research Grant AI-or 944.

Resumen

Preparaciones microscópicas permanentes de los palpos y epiginios de arañas son desvantajosas ya que, al deshidratar las partes esclerozadas se tuercen, se pueden destruir al secarse, y a menudo la preparación es separada del resto del espécimen guardado en alcohol y se pierde. Es mejor guardar los genitales en tubos pequeños (micro- 
vials) (Fig. I), con el espécimen. En especies comunes con numerosos ejemplares, las preparaciones pueden hacerse usando Hoyer o un medio de montaje similar para Acari (Baker and Wharton).

Para ilustrar un palpo, a veces es necesario separarlo de la araña a objeto de orientarlo mejor. En tal caso debería examinarse completamente sumergido en etanol de 75 a $95 \%$. Al secarse las partes blandas se dañan. El palpo se fija en el fondo del recipiente con un pedazo de papel fibroso. El examen se hace con un microscopio binocular de disección entre 150 y 240 aumentos. Los palpos pequeños y transparentes pueden estudiarse transladándolos a glicerina o, si se desea examinarlos con el microscopio compuesto o de fase, a un montaje temporal en glicerina; pero el palpo debe siempre volverse a guardar en alcohol.

Para dilatar el palpo, se hierve por unos minutos en $\mathrm{NaOH}$ al 10\%, entonces se transfiere a agua destilada, y luego se guarda en alcohol. Sin embargo, los escleritos se tuercen y se dañan cuando se hierven en $\mathrm{NaOH}$. Por el momento yo uso ácido láctico en vez de $\mathrm{NaOH}$.

No se debe quitar el epiginio de los ejemplares raros. En especímenes pequeños puede estudiarse sumergiendo todo el animal en aceite de clavo. Dos incisiones (Fig. 2) permiten doblar la región de los genitales hacia atrás (Fig. 3) y, entonces, puede estudiarse después de orientara cuidadosamente (Fig. 4). Más tarde la "puertecita" puede volver a cerrarse. En las arañas pequeñas, el cefalotórax puede separarse a veces con el epiginio todavía fijo al pedicelo (Fig. 5). Algunas veces, en ejemplares que no están bien preservados, los genitales se desprenden o es necesario separarlos para examinarlos en detalle. En tal caso, el epiginio se guarda en un tubo pequeño (Fig. I).

Cuando se trata de preparaciones transitorias, el cefalotórax entero y el epiginio (Fig. 5) pueden montarse en aceite de clavo; o, una preparación temporal del epiginio, para su examen bajo un microscopio compuesto o de fase, puede hacerse con una gota de aceite de clavo cubierta con un cubre-objeto. Para el estudio detallado de especies comunes es necesario, algunas veces, sacrificar un ejemplar y separar con agujas los conductos genitales. Luego, los genitales vuelven a guardarse en alcohol. Solo epiginios con estructuras muy esclerozadas pueden hervirse en $\mathrm{NaOH}$ al $10 \%$. Este método deforma las estructuras e hincha las partes blandas.

Los machos y las hembras de Araneidae son a menudo muy distintos en tamaño y apariencia. Abalos (1963), observó que en muchas especies el extremo del estilo del palpo del macho se desprende durante 
la cópula. El extremo del estilo palpal puede separarse del epiginio de la hembra para aparejar machos y hembras de la misma especie. Este método se aplica con buen éxito en el género Argyope, en el cual la mayor parte de los machos colectados están todavía vírgenes, pues los machos mueren poco despues de la cópula, y la mayor parte de las hembras están fecundadas. Por lo tanto, es muy importante ilustrar cuidadosamente éstos extremos de los estilos masculinos.

\section{Resumé français}

Les préparations microscopiques permanentes sur lame de palpes et épigynes d'araignées ne sont pas désirables. Les parties sclérifiées se déforment par déshydratation et peuvent être écrasées par assèchement et il arrive souvent que la lame soit séparée du reste du spécimen conservé en alcool et se perde. Il est préférable de garder palpes et épigynes dans de petits tubes $(4 \times$ Io $\mathrm{mm}$ ) avec le spécimen (Fig. I). Pour les espèces communes dont on a de nombreux exemplaires on peut monter des lames en utilisant la solution de Hoyer ou bien des solutions semblables pour Acari (Baker et Wharton).

Il se peut qu'on doive séparer un palpe de l'araignée si l'on veut l'orienter correctement pour une illustration. Dans ce cas il faut l'examiner complètement immergé dans de l'éthanol 75 à $90 \%$. Le dessèchement abîme les parties molles. On attache le palpe au fond de la cuvette au moyen d'un morceau de papier fibreux. On procède à l'examen avec une loupe binoculaire grossissant de 150 à 240 fois. Les palpes de petite taille et transparents peuvent être étudiés après être transvasés dans de la glycérine ou bien après montage temporaire sur lame, en glycérine, pour examen au microscope optique ou au microscope à contraste de phase. Le palpe doit cependant être remis en alcool pour conservation.

Pour étendre le palpe on le fait bouillir quelques minutes dans $\mathrm{NaOH} 10 \%$, puis on le transpose dans de l'eau distillée, et enfin on le met dans l'alcool pour conservation. Cependant l'ébullition dans $\mathrm{NaOH}$ déforme et endommage les sclérites. J'emploie maintenant l'acide lactique à la place de $\mathrm{NaOH}$.

L'épigyne ne doit pas être détaché des spécimens rares. Il peut être étudié sur les petits exemplaires en submergeant l'araignée entière dans de l'huile de girofle. Deux incisions (Fig. 2) permettent de courber en arrière la region génitale (Fig. 3), qu'on peut étudier aprés l'avoir soigneusement mise en place (Fig. 4). Par la suite on peut fermer la "porte" ainsi pratiquée. Chez les petites araignées on peut parfois détacher le céphalothorax avec l'épigyne encore fixé au pédicule (Fig. 5). Quelquefois l'épigyne de spécimens mal conservés 
se casse, ou doit être enlevé pour une étude ultérieure plus détaillée. On conserve ensuite l'épigyne dans un petit tube (Fig. I).

Pour des préparations microscopiques temporaires sur lame on peut monter le céphalothorax et l'épigyne entiers dans l'huile de girofle. On peut aussi préparer une lame temporaire en recouvrant l'épigyne avec une goutte d'huile de girofle; une telle préparation protégée par une lamelle peut être alors examinée au microscope optique ou à contraste de phase. Pour les espèces communes dont on fait une étude détaillée il se peut que l'on doive sacrifier un spécimen afin d'écarter les conduits des génitalia au moyen d'aiguilles. On remet ensuite les génitalia en alcool pour conservation. On ne peut faire bouillir l'épigyne dans $\mathrm{NaOH}$ 10\% que si les structures sont fortement sclérifiées. Cette méthode abîme les structures et fait gonfler les parties molles.

Abalos ( I963) a observé que dans de nombreuses espèces l'extrémité de l'embolus du mâle se casse pendant l'accouplement. L'extrémité de l'embolus palpal peut être enlevé de l'épigyne femelle pour assortir máles et femelles (Chez les Araneidae les males et les femelles sont souvent très differents de taille et d'aspect). Ceci se fait maintenant avec succès pour le genre Argyope, chez lequel la plupart des mâles récoltés son vierges, car les mâles meurent peu après l'accouplement, et la plupart des femelles sont accouplées. Par conséquent il est important d'illustrer ces extrémités de l'embolus mâle.

\section{References Cited}

Abalos, J. W. and E. C. Baez

1963. On Spermatic Transmission in Spiders. Psyche 70: 197-207.

BAKER, E. W., AND G. W. Wharton

1952. An Introduction to Acarology. Macmillan, New York.

LEVI, H. W.

1964. The Spider Genus Helvibis (Aradeae, Theridiidae). Trans. Amer. Microscop. Soc. $83:$ 133-143.

Petrunkevitch, A.

1930. The Spiders of Porto Rico. Trans. Connecticut Acad. Arts Sci. $30: 159-355$. 

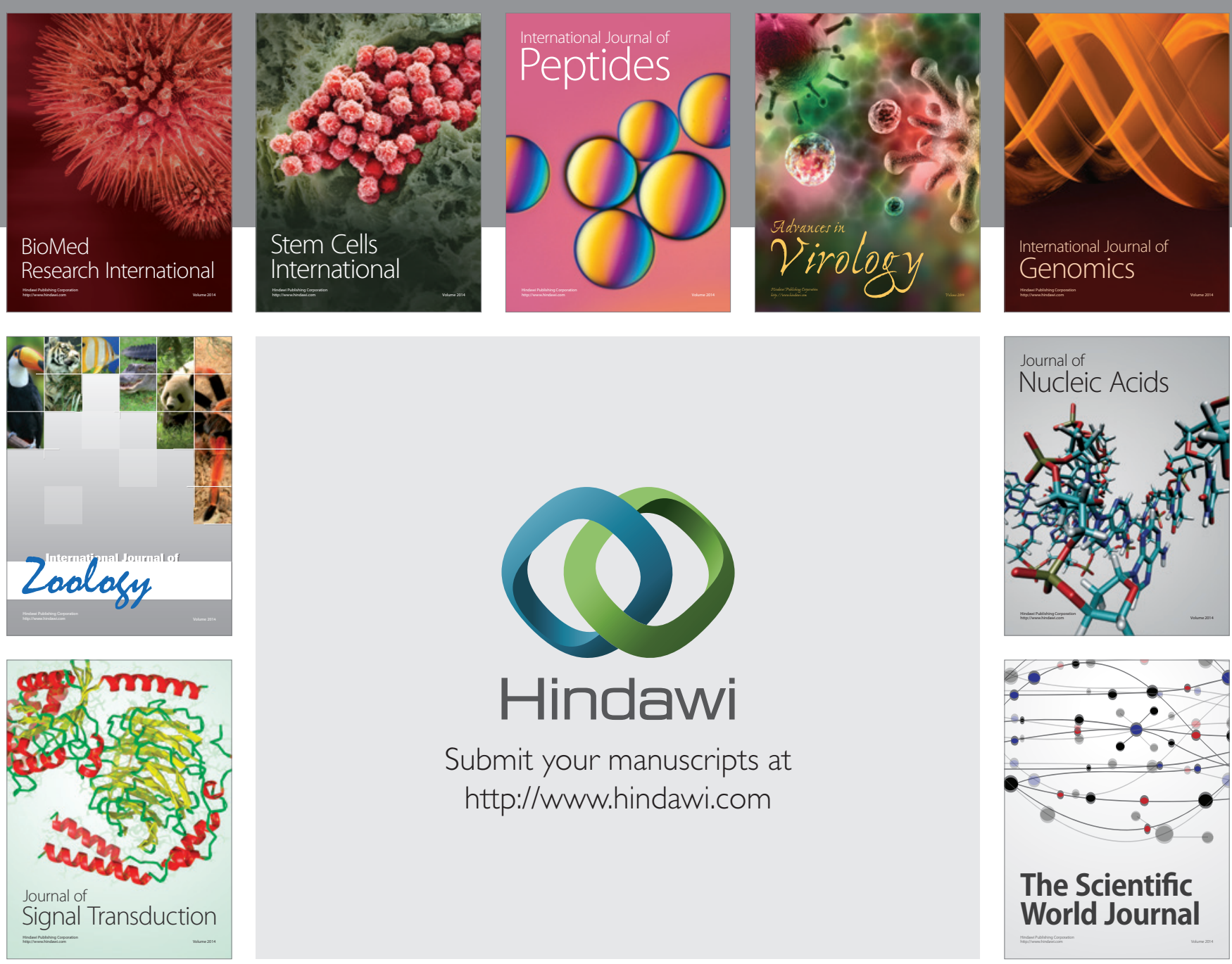

Submit your manuscripts at

http://www.hindawi.com
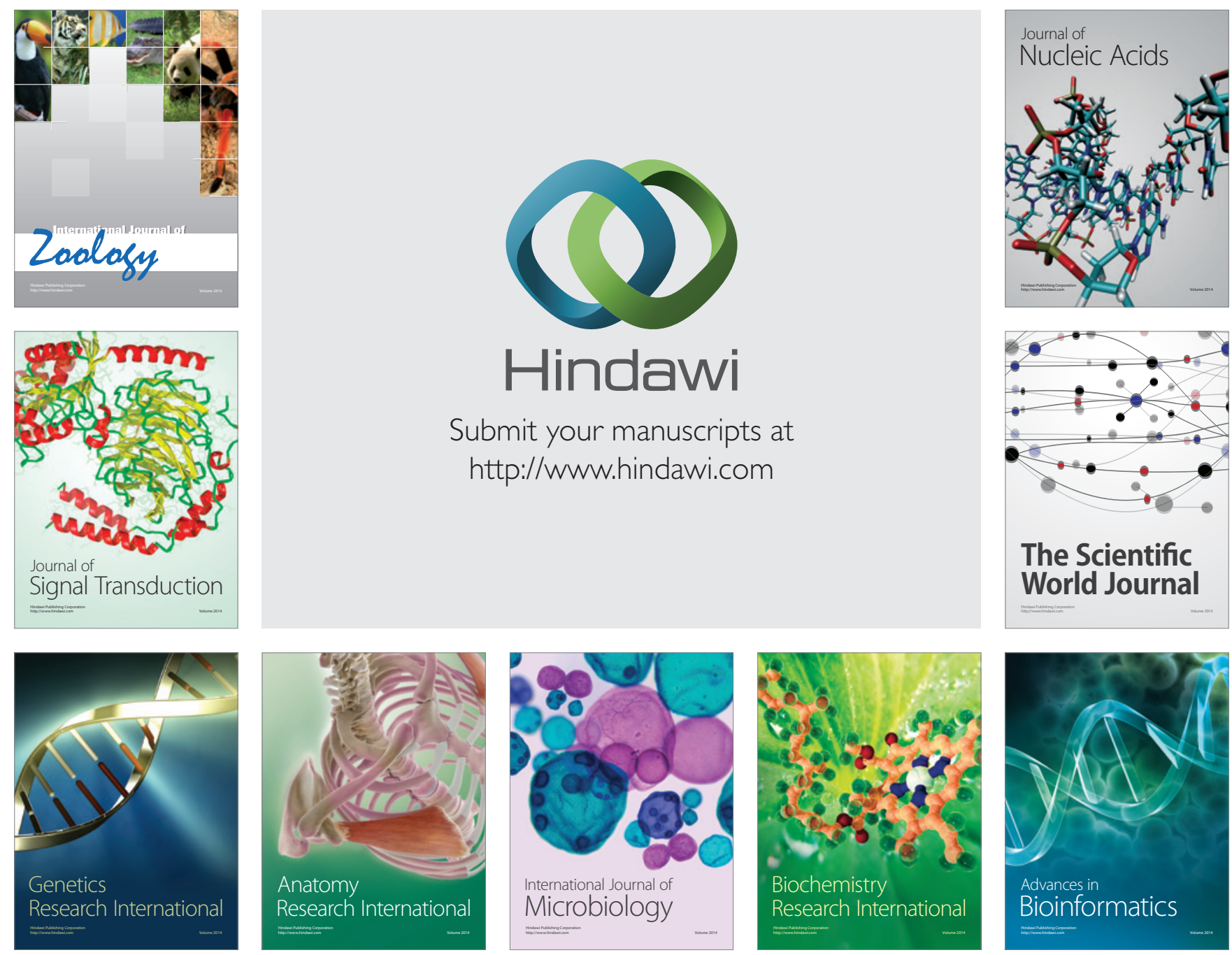

The Scientific World Journal
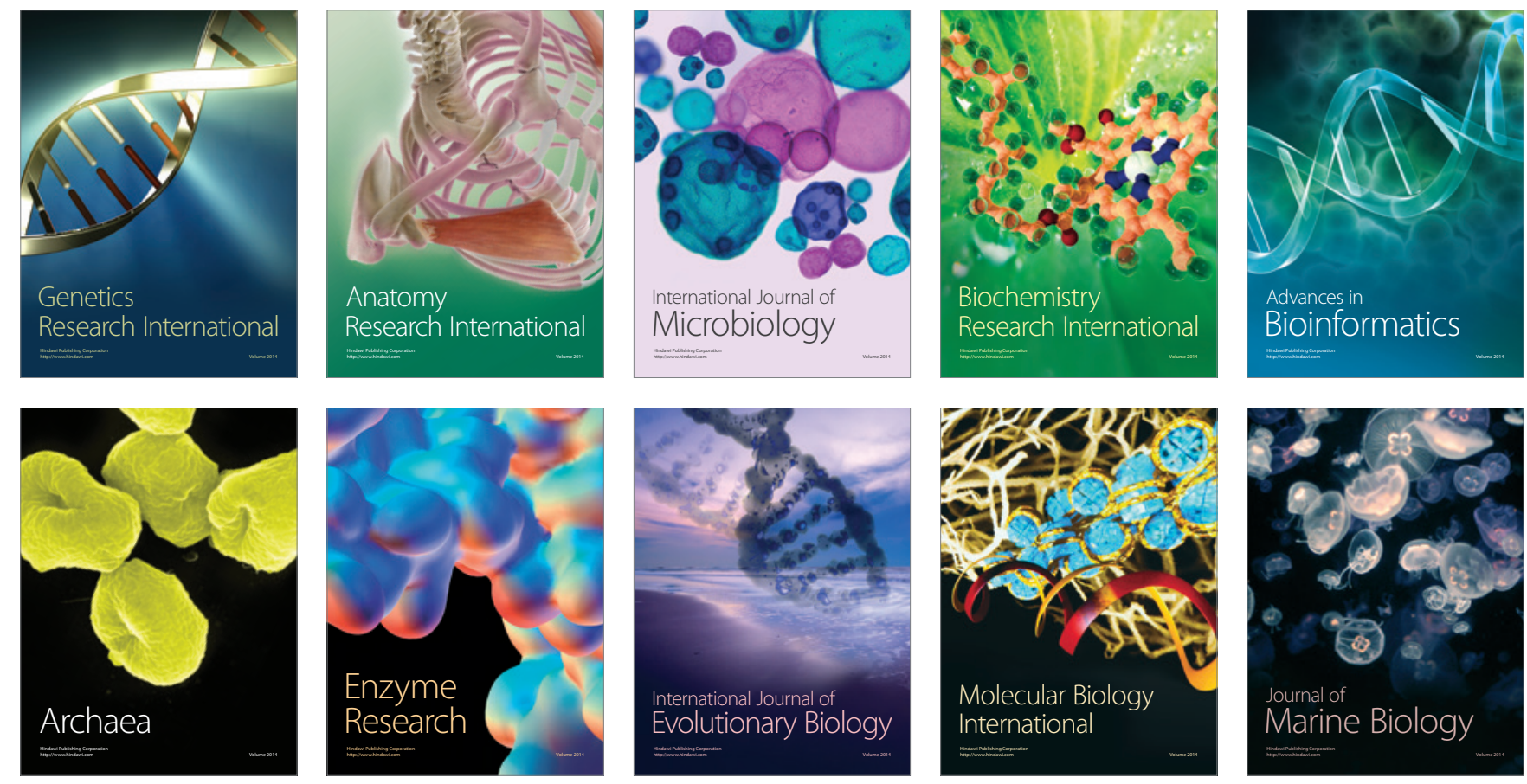